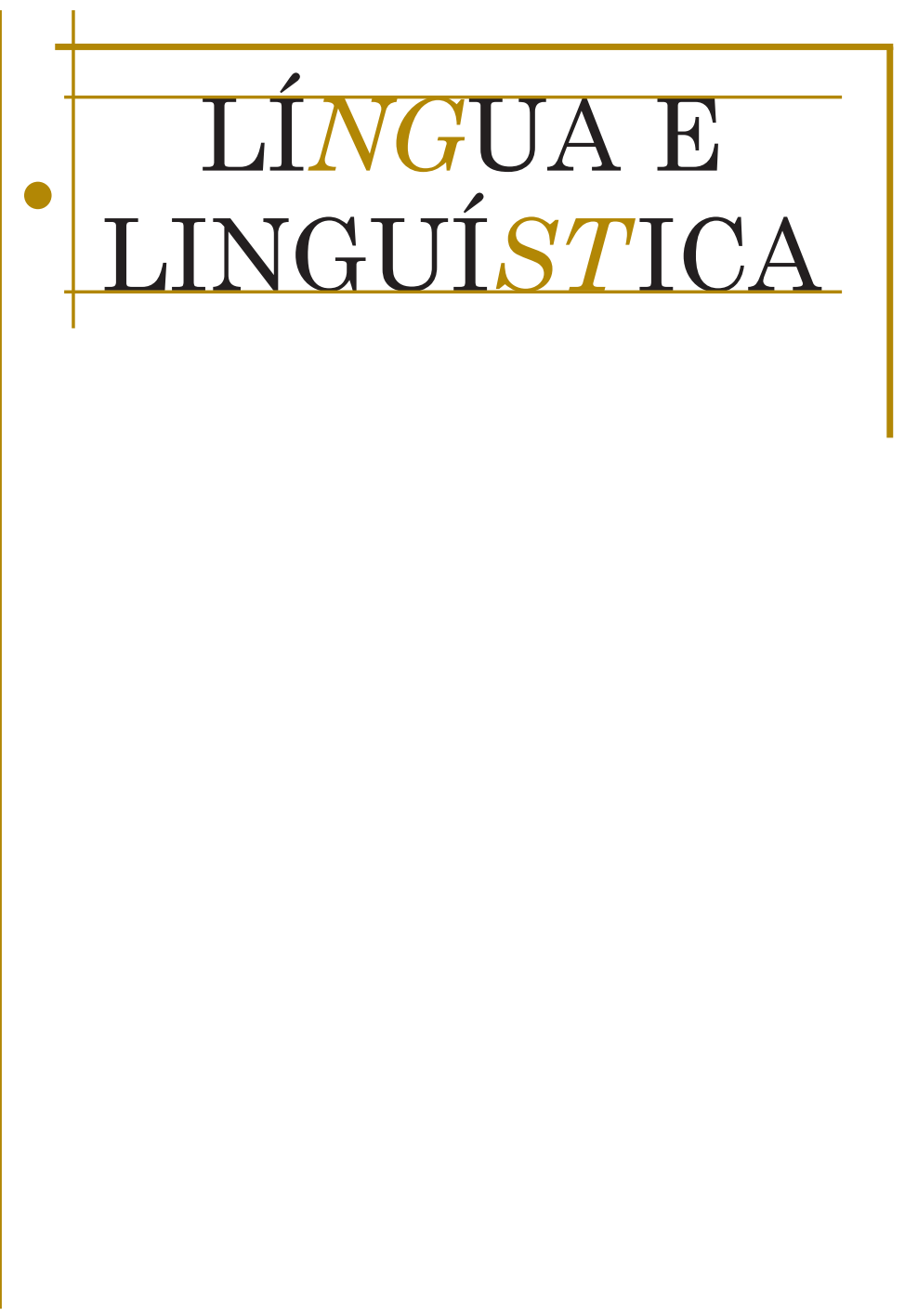




\section{O ENSINO DE GRAMÁTICA NA SALA DE AULA DO ENSINO FUNDAMENTAL}

\section{Ängela Francine Fuza* Ismael Júnior Costa Neto Santos* *}

Resumo: Este trabalho tem como objetivo verificar como as abordagens de ensino de gramática estão sendo implementadas e efetivadas na sala de aula do Ensino Fundamental. Analisam-se, então, as práticas, envolvendo a gramática, em turmas do $8^{\circ}$ ano, observando-se o material didático e as aulas da professora. Os resultados demonstram que as aulas se caracterizam pelo ensino e pela aprendizagem da gramática ainda com perspectivas tradicionais, com foco na gramática normativa e no texto como pretexto para estudo de aspectos linguísticos. O papel do aluno é de receptor dos conhecimentos transmitidos pela professora e pelo livro didático, não condizendo com a proposta da análise linguística, amplamente difundida por estudiosos da linguagem.

Palavras-chave: Ensino. Gramática. Ensino Fundamental.

\section{INTRODUÇÃo}

$\mathbf{A}$

partir de 1980, de acordo com Barbosa (2010), houve no Brasil um processo de mudanças curriculares para a área de Língua Portuguesa, recolocando, no contexto de ensino e de aprendizagem de língua, a questão dos conhecimentos linguísticos/gramaticais. Antunes (2007, p. 21) postula que o ensino de gramática é uma área de equívocos que perpassam a "crença ingênua de que, para se garantir eficiência nas atividades de falar, ler e de escrever, basta estudar gramática (quase sempre nomenclatura gramatical), até a crença, também ingênua, de que não é para se ensinar gramática".

\footnotetext{
* Universidade Federal do Tocantins (UFT) - Porto Nacional - TO - Brasil. E-mail: angelafuza@uft.edu.br

** Universidade Federal do Tocantins (UFT) - Porto Nacional - TO - Brasil. E-mail: bsb_import@yahoo.com.br
} 
Embora novos discursos tenham surgido a respeito do ensino gramatical (GERALDI, 2002, 2003; POSSENTI, 1996; TRAVAGLIA, 1996; BRASIL, 1998; ANTUNES, 2007), a partir de 1980, com a noção de lingua como fruto da interação, não quer dizer que tudo mudou (BARBOSA, 2010). A gramática tradicional ainda ocupa hoje grande tempo das aulas de língua portuguesa, sendo relevante refletir sobre práticas que tendem a uma perspectiva dialógica de linguagem, com foco no trabalho com a análise linguística.

Esta pesquisa foi proposta a fim analisar como as abordagens de ensino de gramática, discutidas a partir dos princípios teóricos da Linguística Aplicada, estão sendo implementadas e efetivadas na sala de aula do Ensino Fundamental em uma escola pública de Porto Nacional, Tocantins. Especificamente, busca-se: 1. identificar a(s) concepção(ões) de linguagem e de gramática que fundamentam a aula. e 2. verificar se as propostas teóricas, ligadas à Linguística Aplicada, que subsidiam a prática da gramática, estão sendo implementadas e efetivadas na sala de aula do Ensino Fundamental.

Para a realização da pesquisa, foram realizadas 12 horas de observação nas turmas do $8^{\circ}$ ano do Ensino Fundamental de Lingua Portuguesa, registrando-se todas as ocorrências e os procedimentos em diário de campo. Além disso, observaram-se: o material didático empregado; as aulas da professora e os exercícios realizados, a fim de verificar se a prática de gramática condizia com os princípios teóricos da Linguística Aplicada sobre gramática/análise linguística. Com esses resultados, possibilitam-se aos cursos de formação de professores subsídios para a preparação de professores que trabalham com a gramática no Ensino Fundamental.

Este artigo, vinculado ao projeto: "A escrita em contextos de ensino e aprendizagem" (UFT) e ao grupo de pesquisa: Práticas de Linguagens - PLES (UFT/ $\mathrm{CNPq}$ ), discorre, na primeira parte, a respeito das concepções de linguagem e de gramática e seu ensino; na segunda, destacam-se a descrição e a discussão das aulas observadas, organizadas em dois momentos: o trabalho com a voz verbal e a conjunção; por fim, há a conclusão.

\section{CoNCePÇões DE LINGUAGEM E DE GRAMÁtica}

Para tratar do ensino de gramática, destacam-se as concepções de linguagem, pois, de acordo com Travaglia (1996, p. 21), a maneira como se concebe a lingua altera "o trabalho com a língua em termos de ensino. A concepção de linguagem é tão importante quanto à postura que se tem relativamente à educação".

Bakhtin/Volochinov (1992) são os responsáveis por tratar das formas de conceber a linguagem a partir de três visões: subjetivismo idealista, objetivismo abstrato e a língua como fenômeno social. Essas foram renomeadas, no Brasil, por Geraldi (2002, 2003), a saber: linguagem como expressão do pensamento, linguagem como instrumento de comunicação e linguagem como forma de interação.

$\mathrm{Na}$ concepção de linguagem como expressão do pensamento, segundo Silva e Mendes (2014, p. 111), “a gramática e [o] uso da língua são entendidos como um produto mental, construído unicamente a partir do pensamento e exteriorizado". Assim, a expressão da linguagem terá um percurso do interior para o exterior, não considerando os fatos externos à comunicação: "A enunciação é um ato monológico, individual, que não é afetado pelo outro nem pelas circuns- 
tâncias que constituem a situação social em que a enunciação acontece" (TRAVAGLIA, 1996, p. 21).

Nessa concepção, a língua é concebida como um produto acabado (BAKHTIN/ VOLOCHINOV, 1992) e a gramática é definida como normativa/prescritiva (TRAVAGLIA, 1996), constituída por um conjunto de regras impostas para falar e escrever bem. Segundo Travaglia (2007, p. 76), não se nega a utilização dessa gramática nos meios sociais, mas a escola não deve impor a chamada variedade "Português padrão e/ou culto" como único modelo de emprego da língua, "mas sim como uma variedade importante [na] sociedade e que devemos usar em dadas circunstâncias".

Segundo Antunes (2003, p. 31-32), o foco em normas linguísticas faz que haja um ensino da gramática "descontextualizada", "fragmentada", "irrelevante", "excêntrica", "inflexível", "voltada para a nomenclatura e classificação". Segundo Doretto e Beloti (2011), é preciso que ocorra um trabalho com a gramática normativa nas escolas, pois é um direito dos sujeitos terem o conhecimento, a fim de exercerem atividades efetivas em relação aos aspectos linguísticos e discursivos. Sendo preciso atentar à metodologia "como a gramática será trabalhada, para que o professor não considere apenas a possibilidade tradicional, como um fim em si mesmo" (DORETTO; BELOTI, 2011, p. 99).

Na segunda concepção, linguagem como instrumento de comunicação, a língua "é vista como um código, ou seja, um conjunto de signos que se combinam segundo regras e que é capaz de transmitir uma mensagem, informações de um emissor a um receptor" (TRAVAGLIA, 1996, p. 22). Para Silva e Mendes (2014), essa perspectiva contribui para a valorização da norma culta como possibilidade única para estudo do texto.

Nessa concepção, foca-se na gramática descritiva (TRAVAGLIA, 2007), que estuda a maneira com que cada indivíduo se expressa, dependendo da região e do seu momento histórico, descrevendo as línguas, e "resulta do trabalho dos linguistas ou estudiosos da língua que buscam dizer [...] como a língua é constituída (quais são suas unidades, categorias, construções) e como ela funciona" (TRAVAGLIA, 2007, p. 74). São realizados estudos de determinados grupos para observar as utilizações das regras da norma culta em detrimento de saber como é o dia a dia da comunidade de falantes, valorizando-se as expressões independentemente de estarem ou não de acordo com a norma padrão ${ }^{1}$.

$\mathrm{Na}$ concepção de linguagem como interação, a linguagem é construída pelos fenômenos sociais da interação verbal. Koch (2002, p. 17) afirma que "o texto passa a ser considerado o próprio lugar da interação e os interlocutores, como sujeitos ativos que - dialogicamente - nele se constroem e são construídos". É por meio do texto que o professor e o aluno terão a oportunidade de trocar informações. A linguagem como interação tem como foco a gramática internalizada (TRAVAGLIA, 2007), que remete a um conjunto de regras que o falante domina e utiliza nas suas comunicações, de modo que as frases e palavras são compreendidas e reconhecidas como pertencentes a uma dada língua.

\footnotetext{
De acordo com Bagno (2002, p. 185), haveria uma distinção entre norma padrão/língua padrão e norma culta/língua culta, logo, não são consideradas sinônimos. No primeiro caso, tem-se o ideal de língua abstrato, "usado como verdadeiro instrumento de repressão e policiamento dos usos linguísticos do outro". No outro, por sua vez, há as variedades cultas, usos reais da língua por parte das classes sociais urbanas com escolaridade superior completa.
} 
Diante das concepções de linguagem, ressalta-se que uma não se opõe a outra, mas, sim, que elas coexistem para que o trabalho em sala de aula se efetive (FUZA; OHUSCHI; MENEGASSI, 2011). Este estudo, assim como Doretto e Beloti (2011), ao adotar uma concepção de linguagem como processo de interação, acredita que seja possivel transitar por todas as concepções e empregar aquilo que é relevante a cada objeto e objetivo de ensino, pois o trabalho com a lingua portuguesa é fruto das concepções de linguagem e de ensino de língua.

\section{O TRABAlHo COM A GRAMÁtica E A ANÁlise linguística EM SALA}

No entendimento de Antunes (2003, p. 93), a questão que se coloca para o professor de português não é a de "ensinar ou não ensinar gramática", mas, sim: "que regras ensinar e em que perspectiva ensinar". Nessa mesma linha, Silva (2011, p. 25) indaga: "o quê ensinar, para quê ensinar e como ensinar gramática", mostrando que seria um questionamento verdadeiro em relação ao ensino de gramática. Os Parâmetros Curriculares Nacionais (PCN) (BRASIL, 1998) trazem as criticas mais frequentes que eram/são feitas em relação ao estudo da gramática normativa:

- a desconsideração da realidade e dos interesses dos alunos;

- a excessiva escolarização das atividades de leitura e de produçãode texto;

- o uso do texto como expediente para ensinar valores morais e como pretexto para o tratamento de aspectos gramaticais;

- a excessiva valorização da gramática normativa e a insistência nas regras de exceção, com o consequente preconceito contra as formas de oralidade e as variedades não-padrão;

- o ensino descontextualizado da metalinguagem, normalmente associado a exercícios mecânicos de identificação de fragmentos linguísticos em frases soltas (BRASIL, 1998, p. 18).

Franchi (1991) aborda alguns métodos para que se possa fugir da supervalorização da gramática normativa no ensino da língua portuguesa, tratando da relação entre a gramática e a criatividade. Franchi $(1991$, p. 8) postula a relevância de exercícios que fogem dos modelos tradicionais, levando o estudante a uma maior reflexão dos assuntos trabalhados em sala. Argumenta ainda que, muitas vezes, o livro didático não tem informações suficientes para que o aluno possa responder aos exercícios de forma consciente.

Para promover os conhecimentos gramaticais aos discentes, é preciso considerar a real necessidade de uso da língua, de modo que "os interlocutores [sejam] sujeitos ativos da dinâmica comunicativa e não meros pacientes da transmissão de conteúdo" (SILVA; MENDES, 2014, p. 114). Apesar de a visão passiva de sujeitos da aprendizagem estar teoricamente ultrapassada, ela ainda é encontrada em livros didáticos, nos quais há a centralização na "transmissão de conteúdo [e no] cumprimento da regra gramatical. [...] o leitor é considerado um sujeito passivo à realização textual” (SILVA; MENDES, 2014, p. 111).

A partir de 1980, segundo Geraldi (2002) e Franchi (1987), tem-se a chamada concepção "operacional e reflexiva da linguagem", que teve o texto como ponto 
de partida para o trabalho de leitura e produção de texto (oral e escrito), utilizando a prática de análise linguística. Remenche e Rohling (2016, p. 98) mostram que essa evolução não está sendo empregada nas escolas como deveria ser feita, pois ainda existe a influência das velhas práticas do ensino de gramática descontextualizado, assim como será constatado neste texto: "no contexto escolar, novas práticas convivem com 'antigas' práticas”.

O ensino de gramática é fundamental nas escolas, principalmente no Ensino Fundamental, foco desta pesquisa. Esse ensino deverá contemplar várias áreas, como Remenche e Rohling (2016) postula: aspectos gramaticais, textuais e discursivos. Silva (2011, p. 25) propõe, também, uma perspectiva gramatical "articulada a atividades didáticas de produção e leitura de textos orais ou escritos", conhecida como análise linguística. Para os PCN:

[a] prática de análise linguística não é uma nova denominação para ensino de gramática. Quando se toma o texto como unidade de ensino, os aspectos a serem tematizados não se referem somente à dimensão gramatical. Há conteúdos relacionados às dimensões pragmática e semântica da linguagem, que [...] precisam, na escola, ser tratados de maneira articulada e simultânea no desenvolvimento das práticas de produção e recepção de textos.

Quando se toma o texto como unidade de ensino, ainda que se considere a dimensão gramatical, não é possível adotar uma categorização preestabelecida. Os textos submetem-se às regularidades linguísticas dos gêneros em que se organizam e às especificidades de suas condições de produção [...] (BRASIL, 1998, p. 78-79).

A análise linguística não é uma nova denominação do ensino de gramática, mas uma evolução do ensino em relação às antigas práticas em sala de aula. $\mathrm{O}$ texto torna-se uma unidade de ensino, o ponto de partida e de chegada do processo de ensino. Porquanto, através dos gêneros, trabalhados em sala de aula, os alunos podem levar o estudo para o seu dia a dia, a sua realidade.

Nessa mesma linha de estudo está Possenti (1996), quando afirma que o ensino deve deixar de ser visto como um simples processo de transmissão de conteúdos prontos, a gramática normativa tradicional, e passar a ser uma tarefa de construção de conhecimentos por parte dos alunos, análise linguística, uma tarefa na qual o professor deixa de ser a única fonte autorizada de informações, motivações e sanções.

Sobre a análise linguística, Geraldi (2002, p. 74) afirma que se trata de um trabalho no qual são abordadas questões tradicionais da gramática e, ao mesmo tempo, questões amplas a propósito do texto: "coesão e coerência internas do texto; adequação do texto aos objetivos pretendidos; análise dos recursos expressivos utilizados (metáforas, metonímias, paráfrases, citações, discursos direto e indireto etc.)".

Diante do exposto, pode-se questionar: qual seria, então, a finalidade e o objetivo do estudo baseado na análise linguística? Para Remenche e Rohling (2015, p. 830), a análise linguística se configura "em instrumental potencializador para as práticas de leitura e de produção de texto (escrita e oral), visto que contribui para a análise do funcionamento da lingua e do uso das diversas variantes linguísticas que circulam socialmente". 
Para que sejam esclarecidas as mudanças na evolução do ensino da gramática, destaca-se o Quadro 1 com as diferenças do ensino tradicional de gramática e da prática de análise linguística:

Quadro 1 - Diferenças entre ensino de gramática e análise linguística

\begin{tabular}{|c|c|}
\hline Ensino de gramática & Prática de análise linguística \\
\hline $\begin{array}{l}\text { Concepção de língua como sistema, } \\
\text { estrutura inflexível e invariável. }\end{array}$ & $\begin{array}{l}\text { Concepção de língua como ação } \\
\text { interlocutiva situada, sujeita às } \\
\text { interferências dos falantes. }\end{array}$ \\
\hline $\begin{array}{l}\text { Fragmentação entre os eixos de ensino: } \\
\text { as aulas de gramática não se relacionam } \\
\text { necessariamente com as de leitura e de } \\
\text { produção textual. }\end{array}$ & $\begin{array}{l}\text { Integração entre os eixos de ensino: a } \\
\text { análise linguística }(\mathrm{AL}) \text { é ferramenta para } \\
\text { a leitura e a produção de textos. }\end{array}$ \\
\hline $\begin{array}{l}\text { Metodologia transmissiva, baseada na } \\
\text { exposição dedutiva (do geral para o } \\
\text { particular, isto é, das regras para o } \\
\text { exemplo) + treinamento. }\end{array}$ & $\begin{array}{l}\text { Metodologia reflexiva, baseada na indução } \\
\text { (observação dos casos particulares para a } \\
\text { conclusão das regularidades/regras). }\end{array}$ \\
\hline $\begin{array}{l}\text { Privilégio das habilidades } \\
\text { metalinguísticas. }\end{array}$ & $\begin{array}{l}\text { Trabalho paralelo com habilidades } \\
\text { metalinguísticas e epilinguísticas. }\end{array}$ \\
\hline $\begin{array}{l}\text { Enfase nos conteúdos gramaticais como } \\
\text { objetos de ensino, abordando } \\
\text { isoladamente e em sequência mais ou } \\
\text { menos fixa. }\end{array}$ & $\begin{array}{l}\text { Ênfase nos usos como objetos de ensino } \\
\text { (habilidades de leitura e escrita), que } \\
\text { remetem a vários outros objetos de ensino } \\
\text { (estruturais, textuais, discursivos, } \\
\text { normativos), apresentados e retomados } \\
\text { sempre que necessário. }\end{array}$ \\
\hline Centralidade na norma padrão. & Centralidade dos efeitos de sentido. \\
\hline $\begin{array}{l}\text { Ausência de relação com as } \\
\text { especificidades dos gêneros, uma vez que } \\
\text { a análise é mais de cunho estrutural e, } \\
\text { quando normativa, desconsidera o } \\
\text { funcionamento desses gêneros nos } \\
\text { contextos de interação verbal }\end{array}$ & $\begin{array}{l}\text { Fusão com o trabalho com os gêneros, na } \\
\text { medida em que contempla justamente a } \\
\text { intersecção das condições de produção } \\
\text { dos textos e as escolhas linguísticas. }\end{array}$ \\
\hline $\begin{array}{l}\text { Unidades privilegiadas: a palavra, a frase } \\
\text { e o período. }\end{array}$ & Unidade privilegiada: o texto. \\
\hline $\begin{array}{l}\text { Preferência pelos exercícios estruturais, } \\
\text { de identificação e classificação de } \\
\text { unidades / funções morfossintáticas e } \\
\text { correção. }\end{array}$ & $\begin{array}{l}\text { Preferência por questões abertas e } \\
\text { atividades de pesquisa, que exigem } \\
\text { comparação e reflexão sobre adequação e } \\
\text { efeitos de sentido. }\end{array}$ \\
\hline
\end{tabular}

Fonte: Mendonça (2009, p. 207). 
Por meio do Quadro 1, verificam-se as distinções entre a metodologia tradicional, pautada por classificação e identificação de elementos linguísticos, e a análise linguística, com foco na reflexão e no uso da língua, considerada espaço de interlocução, possibilitando ao aluno a reflexão. Ao observar a comparação elaborada por Mendonça (Quadro 1), chega-se à conclusão de que, tradicionalmente, o ensino de língua portuguesa pautou-se por um ensino de gramática que, em primeiro lugar, priorizou as atividades de metalinguagem, mostrando prejuízo às atividades de linguagem epilinguísticas. O que a análise linguística mostra é a atividade de metalinguagem como uma fase final do método de ensino (REMENCHE; ROHLING, 2016, p. 106).

A partir da leitura dos teóricos (FRACHI, 1987; GERALDI, 2002, 2003; SILVA, 2011) que tratam dos modos de trabalhar as atividades de gramática, dividindo-as em: linguística, epilinguística e metalinguística, foi organizado o Quadro 2.

Quadro 2 - Conceitos das atividades: epilinguística, linguística e metalinguística

\begin{tabular}{|c|c|c|c|}
\hline Autores & Epilinguística & Linguística & Metalinguística \\
\hline $\begin{array}{l}\text { FRANCHI, } \\
1987\end{array}$ & $\begin{array}{l}\text { - Prática que opera } \\
\text { sobre a própria } \\
\text { linguagem. } \\
\text { - Trata-se de tornar } \\
\text { operacional e ativo um } \\
\text { sistema a que o aluno } \\
\text { já teve acesso fora da } \\
\text { escola, em suas } \\
\text { atividades linguísticas } \\
\text { comuns. } \\
\text { Trata-se de levar os } \\
\text { alunos a diversificar os } \\
\text { recursos expressivos } \\
\text { com que fala e escreve } \\
\text { e a operar sobre sua } \\
\text { própria linguagem. }\end{array}$ & $\begin{array}{l}\text { Exercício pleno, } \\
\text { circunstanciado, } \\
\text { intencionado e com } \\
\text { intenções } \\
\text { significativas da } \\
\text { própria linguagem. } \\
\text { Ela já se dá, } \\
\text { obviamente, nas } \\
\text { circunstâncias } \\
\text { cotidianas da } \\
\text { comunicação no } \\
\text { âmbito da família e } \\
\text { da comunidade de } \\
\text { nossos alunos. }\end{array}$ & $\begin{array}{l}\text { - Procura falar sobre } \\
\text { a própria língua, } \\
\text { descrevê-la num } \\
\text { quadro conceitual } \\
\text { intuitivo ou teórico, } \\
\text { seja pela teoria da } \\
\text { gramática } \\
\text { tradicional, seja } \\
\text { pelos pressupostos } \\
\text { teóricos da ciência } \\
\text { da linguagem. } \\
\text { A capacidade de } \\
\text { falar sobre a } \\
\text { linguagem, } \\
\text { descrevê-la e } \\
\text { analisá-la como } \\
\text { objeto de estudo, } \\
\text { baseado na } \\
\text { gramática } \\
\text { normativa. }\end{array}$ \\
\hline
\end{tabular}


Quadro 2 - Conceitos das atividades: epilinguística, linguística e metalinguística (continuação)

\begin{tabular}{|c|c|c|c|}
\hline Autores & Epilinguística & Linguística & Metalinguística \\
\hline $\begin{array}{l}\text { GERALDI, } \\
2002,2003\end{array}$ & $\begin{array}{l}\text { - Atividade de reflexão } \\
\text { sobre o já-conhecido } \\
\text { para aprender o } \\
\text { desconhecido e } \\
\text { reproduzir o novo. } \\
\text { - Reflexão do texto lido } \\
\text { ou escrito para que se } \\
\text { chegue a uma } \\
\text { construção de sentido } \\
\text { ao texto. }\end{array}$ & $\begin{array}{l}\text { Praticada nos } \\
\text { processos } \\
\text { interacionais, } \\
\text { refere-se ao } \\
\text { assunto em pauta, } \\
\text { permitindo a sua } \\
\text { progressão. }\end{array}$ & $\begin{array}{l}\text { Toma a linguagem } \\
\text { como objeto não } \\
\text { mais enquanto } \\
\text { reflexão vinculada } \\
\text { ao próprio processo } \\
\text { interativo. }\end{array}$ \\
\hline $\begin{array}{l}\text { SILVA, } \\
2011\end{array}$ & $\begin{array}{l}\text { - É definida como uma } \\
\text { prática estimulada e } \\
\text { consciente da } \\
\text { linguagem, com } \\
\text { variação dos recursos } \\
\text { expressivos e formais } \\
\text { como meio de obter } \\
\text { novos efeitos de } \\
\text { sentido. } \\
\text { É um trabalho sobre a } \\
\text { própria linguagem. }\end{array}$ & $\begin{array}{l}\text { - O próprio ato de ler } \\
\text { e escrever; } \\
\text { corresponde à } \\
\text { atividade de uso } \\
\text { espontâneo da } \\
\text { língua em qualquer } \\
\text { ambiente e } \\
\text { situação, realiza-se } \\
\text { em textos orais ou } \\
\text { escritos. }\end{array}$ & \\
\hline
\end{tabular}

Fonte: Elaborado pelos autores.

O Quadro 2 evidencia que a atividade com foco na gramática tradicional é vinculada às práticas metalinguísticas; já as epilinguísticas estão mais voltadas à reflexão sobre a língua, análise linguística. Esta tem a função primordial de potencializar as práticas de leitura e de produção de texto (oral e escrita), na sala de aula, contribuindo para uma análise do funcionamento da língua e do uso das diversas variantes linguísticas. No entanto, para que isso ocorra, as atividades em sala de aula devem ir além de aspectos da metalinguagem, baseado em conceitos, tendo como objetivo o trabalho em sala de aula com a dimensão interacional e discursiva da língua, para que os conteúdos se articulem em torno de dois eixos: o uso da língua oral e escrita e a reflexão acerca desses usos (REMENCHE; ROHLING, 2016).

Diante do exposto, discute-se, hoje, sobre o trabalho com a análise linguística em sala de aula e questiona-se sua aplicabilidade nas escolas, uma vez que, conforme já exposto, até mesmo os livros didáticos apresentam um trabalho tradicional de ensino de gramática. Na seção seguinte, parte-se para a análise das atividades envolvendo gramática em sala de aula, a fim de verificar de que modo essa prática é contemplada. 


\section{As aulas de gramática em sala de aula}

Para alcançar o objetivo proposto de analisar como as abordagens de ensino de gramática, propostas a partir dos princípios teóricos da Linguística Aplicada, estão sendo implementadas e efetivadas na sala de aula, foram realizadas 12 horas de observação nas aulas de lingua portuguesa de duas turmas de $8^{\circ}$ anos do Ensino Fundamental (tendo uma média de 23 alunos em cada). Durante as observações, os dados foram coletados por meio de diário de campo. Ademais, foram feitas cópias das atividades do livro didático, principal instrumento de ensino, utilizado nas aulas, e das atividades repassadas aos alunos.

Tendo em vista que as temáticas das aulas de gramática, nos $8^{\circ}$ anos, foram: voz verbal e conjunção, a análise das aulas foi organizada a partir desses assuntos. Na seção seguinte, destacam-se as descrições e as análises das aulas observadas, discutindo-se o tipo de ensino de gramática proposto e se há a tentativa de trabalho com a análise linguística em sala de aula, conforme Quadro 1 exposto em seção anterior, que demonstra as diferenças entre ensino de gramática e de análise linguística.

\section{O TRABALHO COM A VOZ VERBAL}

As primeiras observações foram no $8^{\circ}$ ano 01 , com foco nas vozes verbais e nas conjunções. Para introduzir o primeiro conteúdo, a professora iniciou com a construção do conceito por meio de atividade constante no livro didático:

\section{Construindo o conceito}

Leia esta tira, de Fernando Gonsales:
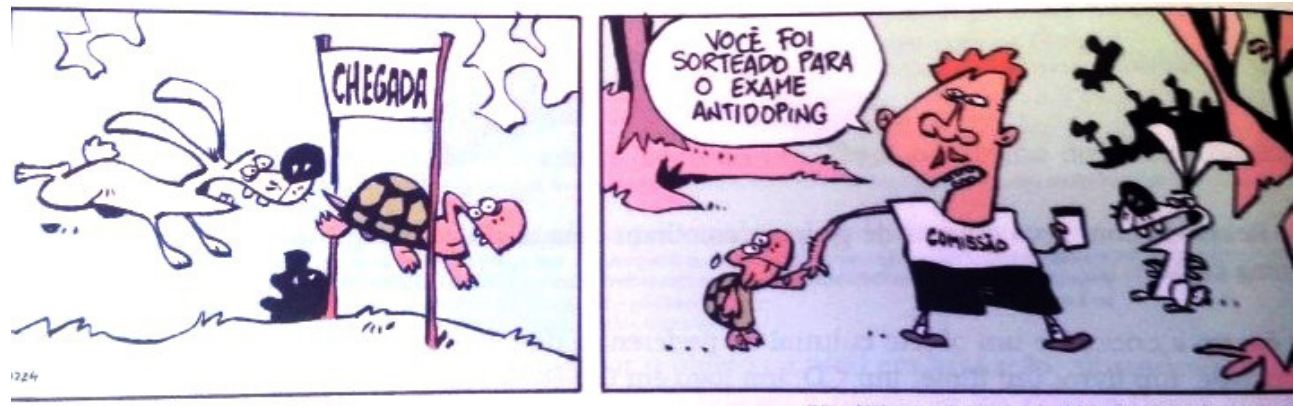

(Niquel Nouseo - A pererecu do viainha. Sto Pasio: Deair, 2005

1. A tira cita uma fábula conhecida, estabelecendo com ela uma relação de intertextualidade.
A) Qual é a fábula citada?
B) Na fábula citada, por que a tartaruga vence a corrida?
C) Que fato surpreendente e atual modifica a fábula citada?
D) Por que a tartaruga manifesta surpresa? 
2. Em relação à frase "Você foi sorteado para o exame antidoping":

a) Indique o sujeito e o predicado.

b) Quem recebe a ação verbal expressa em foi sorteado?

c) Levante hipóteses: Quem pratica a ação verbal?

d) Reescreva a frase, empregando a expressão a comissão como sujeito da oração.

Fonte: Cereja e Magalhães (2012, p. 60-61).

A educadora pediu para que os alunos respondessem os exercícios 1 e 2, foi dado tempo de 10 minutos. Após, ela falou que iria ler e os alunos iriam respondendo juntamente com ela. Alguns alunos participaram, enquanto era lida a questão 1, outros ficaram dispersos, falando e fazendo coisas que não tinham relação com a aula. Quando a docente iniciou a questão 2, a desatenção tornou-se geral, não estavam respondendo, apenas uma aluna respondia.

Quanto ao livro didático, percebe-se, nessa parte, "construindo o conceito", que há a predominância da gramática tradicional, mesmo com um trabalho de leitura da história em quadrinho. Ela é trabalhada como pretexto, ou seja, o texto é usado como meio para ensinar e aprender a gramática, focando nos seguintes itens gramaticais: "sujeito", "predicado", "ação verbal" que deveriam ser localizados: "Indique o sujeito e o predicado", por exemplo.

A teoria entende a primeira parte da aula, no 8.01, como uma aula que tem como base a gramática normativa, apesar de o exercício 1 não ser de gramática, mas trabalhar a leitura. Esse exercício de leitura levanta os conhecimentos prévios do aluno e também o faz analisar o texto, o foco nesse exercício foi a busca do conhecimento prévio do aluno, através da inferência à fábula da lebre e da tartaruga. A pergunta 2 é extremamente tradicional com o foco na gramática, observa-se que o texto não é valorizado. A valorização ficou apenas na gramática tradicional, com exercícios estruturais, por meio de periodos, de palavras e de frases, que objetivam a indicação do sujeito e do predicado, da ação verbal. O texto é visto como pretexto de trabalho com a gramática normativa. Segundo Mendonça (2009, p. 207), a aula foi baseada na gramática, "ausência de relação com as especificidades dos gêneros, uma vez que a análise é mais de cunho estrutural e, quando normativa, desconsidera o funcionamento desses gêneros nos contextos de interação verbal”, ao mesmo tempo, a unidade privilegiada é a palavra, a frase e o período.

$\mathrm{Na}$ segunda parte da aula, após a resolução dos exercícios, iniciou-se a leitura das páginas 61 e 62 que explicam o conteúdo "Vozes do verbo". A professora leu o que estava no livro didático (LD), mas nada foi escrito no quadro. Nessa parte da aula, os alunos não tiveram participação, só escutavam o que era transmitido pela professora sobre a parte conceitual. 


\section{Conceituando}

Observe esta oração:

A tartaruga foi sorteada pela comissão para o exame antidoping.

Nela, a tartaruga desempenha a função de sujeito, mas não é ela quem realiza a ação verbal. Como a tartaruga é quem sofre a ação expressa pela forma verbal foi sorteada, dizemos que esse termo desempenha função de sujeito paciente.

Contudo, se tivéssemos "A comissão sorteou a tartaruga", o sujeito seria a comissão e se trataria de um sujeito agente.

O sujeito ainda pode ser, ao mesmo tempo, agente e paciente da ação verbal. Isso se verifica em orações como "A tartaruga feriu-se", em que o sujeito pratica e recebe a ação expressa pela forma verbal.

Veja outros exemplos:

A chuva provocou inundações no centro da cidade.

Sujeito agente

As joias foram encontradas no porta-malas do carro pela polícia.

Sujeito paciente

As crianças machucaram-se naqueles brinquedos velhos.

Sujeito agente

E paciente

Voz é a forma tomada pelo verbo para indicar a relação entre a ação expressa por ele e o sujeito. Essa relação pode ser de atividade, de passividade ou de atividade e passividade ao mesmo tempo.

Assim, as vozes verbais são três: ativas, passiva e reflexiva.

\section{Voz ativa}

Indica que a ação expressa pelo verbo é praticada pelo sujeito:

A comissão sorteou a tartaruga para o exame antidoping.

sujeito agente voz ativa

\section{Voz passiva}

Indica que a ação expressa pelo verbo é recebida pelo sujeito:

A tartaruga foi sorteada pela comissão para o exame antidoping.

$$
\text { sujeito voz passiva }
$$

paciente 


\section{Voz reflexiva}

Indica que a ação expressa pelo verbo é praticamente e recebida pelo sujeito:

A tartaruga se leva no lago.

sujeito voz reflexiva

Fonte: Cereja e Magalhães (2012, p. 61-62).

Quando a professora lê o conteúdo do livro, "conceituando", observa-se que o conteúdo foi transmitido através se sua leitura, prevalecendo a concepção de linguagem como expressão do pensamento, já que é somente a professora a única detentora do saber. O ensino também é somente da transmissão de conteúdos de gramática. Essa segunda parte foi ministrada também ao 8.02, juntamente com a resolução dos exercícios tradicionais das páginas 63-64. Com base em Mendonça (2009, p. 207), há, então, a "Ênfase nos conteúdos gramaticais como objetos de ensino, abordando isoladamente e em sequência mais ou menos fixa". Ademais, assim como postula Possenti (2011, p. 162), não há o foco nos "efeitos que podem ser produzidos em um texto, conforme o sujeito esteja, por exemplo, explicitado ou não, em sua posição típica ou posposto etc.”.

As atividades, de modo geral, fundamentam-se na concepção de linguagem como expressão do pensamento, pois: "A enunciação é um ato monológico, individual, que não é afetado pelo outro nem pelas circunstâncias que constituem a situação social em que a enunciação acontece" (TRAVAGLIA, 1996, p. 21), ao mesmo tempo, na concepção como instrumento, na qual o aluno torna-se um sujeito obrigado, unicamente, a capturar a mensagem, um saber externo e indiferente a ele (SILVA; MENDES, 2014, p. 113). Portanto, a aula foi baseada somente no LD, sem nenhuma influência do meio, tendo como foco a gramática. Segundo Mendonça (2009), há "Metodologia transmissiva, baseada na exposição dedutiva (do geral para o particular, isto é, das regras para o exemplo) + treinamento".

Após a leitura da parte conceitual, a professora estipulou 30 minutos para que os alunos respondessem os exercícios das páginas 63 e 64: 


\section{Exercícios}

Leia a tira a seguir, de Angeli, e responda às questões 1 e 2 .
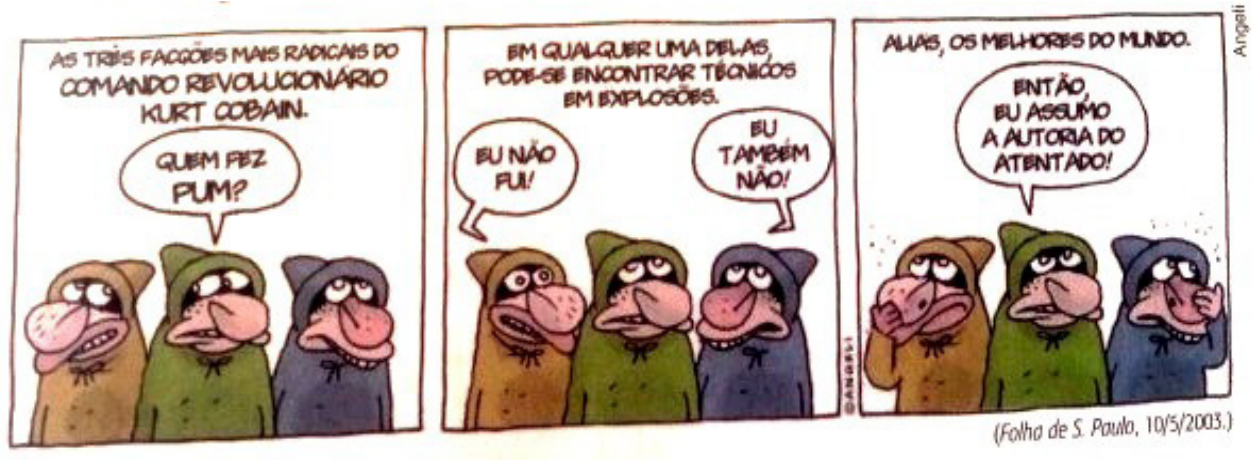

1. A oração do balão do $3^{\circ}$ quadrinho está na voz ativa. Passe-a para uma das modalidades da voz passiva.

2. Observe agora a legenda do $2^{\circ}$ quadro.

a) A oração dela está na voz ativa ou na passiva?

b) A concordância do verbo com o sujeito está de acordo com as regras da norma-padrão? Por que? Se não, qual seria a forma adequada?

3. Leia este texto, extraído da revista língua portuguesa:

"Cerca de 300 Línguas africanas foram trazidas ao Brasil, principalmente da África ocidental (grupo banco e ioruba). Ao que tudo indica, vieram 3,8 milhões de negros, bem mais que os 800 mil enviados aos Estados Unidos”. (Língua Portuguesa, ${ }^{\circ} 2$ p. 55 )

a) Em que voz verbal está a primeira oração do texto?

b) Passe essa oração para a voz passiva sintética.

4. No trecho "Ao que tudo indica, vieram 3,8 milhões de negros, bem mais que os 800 mil enviados aos Estados Unidos", há três verbos e, consequentemente, três orações. Identifique a voz em que está cada uma delas.

5. Transforme a voz passiva analítica dos verbos das seguintes orações em voz passiva sintética. Atente para a concordância do verbo com o sujeito. Veja o exemplo:

As inscrições para o torneio de vôlei já foram encerradas. Encerraramse as inscrições para o torneio de vôlei.

a) Os lanches naturais foram vendidos rapidamente.

b) O carro foi comprado por um bom preço. 
c) Foram mencionados outros alunos para o campeonato.

d) Esta marca de computador não é conhecida.

e) Flores foram atiradas nos manifestantes.

Fonte: Cereja e Magalhães (2012, p. 63-64).

Com o passar dos 30 minutos, o pesquisador observou que poucos tentavam responder, outros não faziam nada, e alguns só passavam as questões para o caderno, porém não tentavam respondê-las. A professora pediu para que os alunos que terminassem de responder, levassem a atividade até ela para que fosse dado o visto. Durante a aula, o pesquisador ${ }^{2}$ questionou uma aluna:

PE: "a professora não irá corrigir as respostas?"

A: "Ela vai corrigir depois, na próxima aula".

$P E$ : "Como será essa correção?"

A: "A professora vai falando e nós iremos corrigindo no caderno".

As turmas dos $8^{\circ}$ anos tiveram aula no mesmo dia, sendo assim, destacam-se algumas atitudes e atividades que se diferem de uma turma para a outra. No caso da turma 2, foi trabalhada a continuação da seção "conceituando". Ao entrar em sala, a professora pediu aos alunos: "Abram os cadernos, sobre a teoria que passei na segunda feira, Vozes do verbo. Não vou colocar nada no quadro, prestem atenção: 'O que é vozes do verbo?"'.

Nesse momento, toda a turma leu o que estava escrito no livro didático e respondeu:

A: "Voz é a forma tomada pelo verbo para indicar a relação entre a ação expressa por ele e o sujeito. Essa relação pode ser de atividade, de passividade ou de atividade e passividade ao mesmo tempo".

$P$ : "E qual a definição para o que vocês leram?".

A turma ficou calada após a pergunta da professora. Ela só falou que essa voz pode ser ativa, passiva e reflexiva, e continuou lendo sobre as vozes do verbo.

A aula foi baseada somente no que estava no LD. Quando terminou a explicação oral sobre o conteúdo do livro, a docente pediu para que eles respondessem as atividades das páginas 63 e 64, questões de 1 a 5, as mesmas da turma 1 .

$\mathrm{Na}$ aula seguinte, turma 2, o objetivo foi a correção dos exercícios das páginas 63 e 64. A professora, antes de iniciar a correção, deixou bem claro: "prestem atenção nas respostas, pois não irei repeti-las”. A correção foi iniciada, a professora pediu para que os alunos respondessem a primeira questão, fez uma breve explicação, as respostas deles não tinham nexo com as perguntas, ela respondeu o que estava no LD, pois o pesquisador viu as respostas do livro do professor. $\mathrm{Na}$ questão 2, a professora só leu a pergunta, não fez nenhuma explicação, todos foram respondendo oralmente, até uma aluna responder corretamente de acordo

2 A fim de manter em sigilo a identidade dos participantes, serão utilizados: "PE", para se referir ao pesquisador; " $P$ ", para se referir à professora; "A", para se referir aos alunos, havendo a gradação: $A 1$, A2 etc. quando houver mais de um aluno. 
com o livro. A questão 3, os alunos não responderam de acordo com LD, a professora levantou e colocou a resposta no quadro sem dar nenhuma explicação: 1. "voz passiva analítica", 2. "Trouxeram-se cerca de 300 linguas africanas".

Na questão 4, o pesquisador observou, pelas respostas dos alunos, que não sabiam identificar as orações; a professora colocou a resposta no quadro e não fez nenhuma explicação e nem perguntou se eles tinham alguma dúvida. A questão 5 foi respondida por uma aluna corretamente, então a professora pediu para que ela a ditasse para os demais colegas.

A predominância da correção foi oral, a professora falava enquanto os alunos escreviam no caderno. Durante a correção, alguns alunos não copiavam as respostas, talvez por não entenderem o conteúdo.

Na questão 5, da página 64, alternativa "d": "Esta marca de computador não é conhecida", um aluno perguntou, após a leitura da professora: "professora, 'esta' é verbo?”. A professora não respondeu, o aluno não fez o questionamento novamente e a aula continuou. As respostas das questões estavam prontas no LD, se respondessem outra coisa para a professora, era considerado errado. Portanto, não houve diálogo entre professor, aluno e material didático para a construção das respostas, tendo em vista que as vozes do livro didático e do professor predominaram.

\section{O TRABalho COM A CONJUNÇÃo}

Foram observadas duas aulas no $8^{\circ}$ ano, turma 1 , nos dias 28 e 29 , que tinham como foco o estudo das conjunções. Diferentemente das aulas sobre vozes verbais, iniciadas com um texto, nas aulas sobre conjunção o foco recaiu diretamente no conceito, conforme se observa.

\section{- A Língua em foco}

A CONJUNÇÃO (I)

Construindo o conceito

Leia este texto, de Carlos Drummond de Andrade:

\section{MANEIRA DE AMAR}

O jardineiro conversava com as flores, e elas se habituaram ao diálogo. Passava manhãs contando coisas a uma cravina ou escutando o que lhe confiava um gerânio. O girassol não ia muito com sua cara, ou porque não fosse homem bonito, ou porque os girassóis são orgulhosos de natureza.

Em vão o jardineiro tentava captar-lhe as graças, pois o girassol chegava a voltar-se contra a luz para não ver o rosto que lhe sorria. Era uma situação bastante embaraçosa, que as outras flores não comentavam. Nunca, entretanto, o jardineiro deixou de regar o pé de girassol e de renovar-lhe a terra, na devida ocasião.

O dono do jardim achou que seu empregado perdia muito tempo parado diante dos canteiros, aparentemente não fazendo coisa alguma. E mandou-o embora, depois de assinar a carteira de trabalho. 
Depois que o jardineiro saiu, as flores ficaram tristes e censuravam-se porque não tinham induzido o girassol a mudar de atitude. A mais triste de todas era o girassol, que não se conformava com a ausência do homem. "Você o tratava mal, agora está arrependido?" "Não, respondeu, estou triste porque agora não posso tratá-lo mal. É minha maneira de amar, ele sabia disso, e gostava".

Carlos Drummond de Andrade ANDRADE, C. D. Contos plausíveis. Rio de Janeiro: J. Olympio Editora, 1985.

1. Observe as personagens descritas no texto. O jardineiro possui sensibilidade e delicadeza de sentimentos.

a) Que ações da personagem comprovam isso?

b) As flores gostam dele? Justifique sua resposta com elementos do texto.

2. Quando o jardineiro foi embora, as flores se culparam por não terem persuadido o girassol a mudar de atitude. Entretanto, o girassol era o que mais sentia a ausência do jardineiro.

a) O jardineiro sabia a razão de o girassol tratá-lo mal? Justifique sua resposta.

b) Na sua opinião, existem entre os homens pessoas que têm uma maneira de amar parecida com a do girassol? Existem pessoas que sabem disso e compreendem essa maneira de amar?

Fonte: Cereja e Magalhães (2012, p. 199-200).

A primeira atitude da professora, após cumprimentar os alunos, foi iniciar copiando o conteúdo sobre conjunção do livro no quadro.

\section{Conceituando}

As orações se relacionam umas com as outras por meio de uma palavra ou expressão que as liga. Essa palavra ou expressão é chamada de conjunção. As relações que as conjunções estabelecem são um dos fatores responsáveis pela textualidade, ou seja, elas contribuem para que um texto seja coerente e coeso, e não uma sequência de palavras ou frases sem sentido.

As conjunções relacionam também termos semelhantes da mesma oração. Veja os exemplos:

$\underline{\text { O jardineiro } \underline{\mathbf{e}} \text { as flores se entendiam. Ele conversava com o girassol } \underline{\mathbf{e}} \mathrm{com}}$ as outras flores. 
Assim, concluímos:

Conjunção é a palavra ouexpressão que relaciona duas orações ou dois termos de mesmo valor sintático.

Duas ou mais palavras que, juntas, exercem o papel de conjunção, são chamadas de locução conjuntiva: já que, se bem a fim de, etc.

Depois que o jardineiro foi embora, as flores ficaram tristes.

Fonte: Cereja e Magalhães (2012, p. 200-201).

Pelo fato de ter algo no quadro, os alunos se comportavam, mas, depois de copiarem, iniciavam as conversas. A aula terminou.

No dia seguinte, a professora selecionou a frase da página 201, não colocou nada no quadro, só leu:

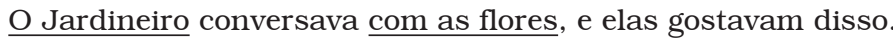

\begin{tabular}{l|ll} 
Sujeito VTI OI & sujeito VTI OI \\
conjunção & &
\end{tabular}

Depois de toda a leitura da parte conceitual sobre conjunção, ela falou aos alunos que eles respondessem as questões de 1 a 4, das páginas 201 e 202:

\section{EXERCÍCIOS}

1. Leia esta tira, de Fernando Gonsales:
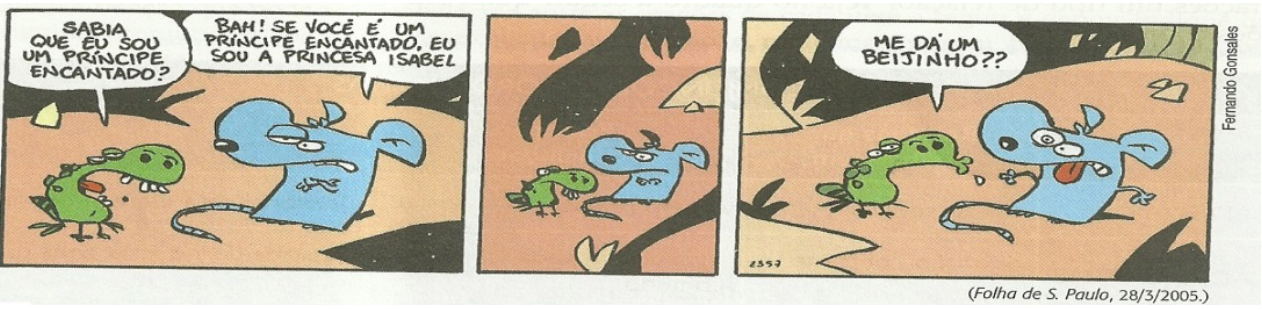

Se eliminarmos a palavra que do $1^{\circ}$ balão da tira, teremos:

Sabia eu sou um príncipe encantado?

a) Qual é a predicação do verbo saber?

b) Essas orações dependem uma da outra sintaticamente?

c) Então conclua: A conjunção que é coordenativa ou subordinativa? 
2. Identifique as conjunções neste texto:

Às vezes, no final da temporada de verão, quando os turistas iam embora de Calella, ouviam-se uivos vindos do morro. Eram os clamores dos cachorros amarrados nas árvores.

Os turistas usavam os cachorros, para alívio da solidão, enquanto as férias duravam, e depois, na hora de partir, os cachorros eram amarrados morro acima, para que não seguissem os turistas que partiam.

(Eduardo Galeano. O livro dos abraços. 9. ed. Porto Alegre: LePM, 2002, p. 184.)

3. Leia a anedota:

Uma pessoa dirige-se a um advogado, o mais caro da cidade:

-Eu sei que o senhor é um advogado caro, mas por mil reais posso lhe fazer duas perguntas?

$\mathrm{O}$ advogado responde:

-Claro! Qual é a segunda? (Donaldo Buchweitz. Piadas para você morrer de rir. Belo Horizonte: Leitura, 2001, p. 33.)

Em relação à frase "Eu sei que o senhor é um advogado caro", responda:

a) Quantas orações há nesse enunciado?

b) Entre as orações, há uma conjunção que se liga. Qual é ela?

c) Essa conjunção é coordenativa ou subordinativa?

4. A anedota é um gênero textual que normalmente rompe com as expectativas do leitor. $\mathrm{Na}$ anedota reproduzida no exercício anterior, qual foi a expectativa quebrada?

Fonte: Cereja e Magalhães (2012, p. 201-202).

À medida que fossem terminando teriam que levar para que ela desse um visto e, na próxima aula, seria corrigido.

A turma 2 do $8^{\circ}$ ano também teve aulas com o foco no estudo das conjunções, nos dias 28 e 29. O conteúdo foi ministrado da mesma forma da turma 1 . Durante a leitura da professora e explicação da parte conceitual, do dia 28, uma aluna perguntou, enquanto a professora copiava no quadro:

A: "professora, o que é subordinar? Seria a mesma relação em que um faz ao outro, um chefe e o empregado?".

$P$ : "não, o mesmo sentido aqui é totalmente diferente". 
A educadora não explicou o que seria e por qual motivo não tinha uma ligação da conjunção subordinada em relação ao patrão e ao empregado. A relação estabelecida pela aluna foi muito interessante, pois fez um vínculo entre a conjunção subordinada e o trabalho do dia a dia. Observa-se que a conjunção subordinada não tem relação, da mesma forma que o patrão, de autoridade de um sobre o outro, mas de dependência, pois o empregado precisa do patrão, assim como o patrão precisa do empregado (fazendo uma analogia da gramática normativa com a vida, portanto, poderia ser uma oportunidade para uma excelente aula de análise linguística, linguagem como interação). As conjunções subordinadas têm uma dependência de ligação entre duas orações, assim como o patrão e o funcionário, seriam as orações e o trabalho a conjunção, a oração principal necessita da subordinada para que se tenha uma ideia coerente.

Após, a educadora encerrou os registros no quadro e deu um prazo para eles terminarem. Nenhum questionamento foi levantado, só a da aluna em relação à subordinação. O conteúdo foi transmitido aos alunos sem nenhum apoio metodológico externo ao LD.

No dia seguinte, os alunos tiveram uma explicação da parte conceitual com a mesma frase utilizada na turma 1, "O Jardineiro conversava com as flores, e elas gostavam disso", a metodologia foi a mesma, de leitura e de transmissão de conhecimento da professora aos alunos, não houve uma interação.

Nas aulas sobre conjunção, a concepção de linguagem que respalda é a linguagem como instrumento, já que a professora só passava o que estava no livro aos alunos, um ensino que, segundo Silva e Mendes (2014, p. 113), seria uma "valorização da norma culta como única possibilidade para entendimento do texto. Dentro das práticas didáticas, o aluno torna-se um sujeito obrigado unicamente a capturar a mensagem, um saber externo e indiferente a ele".

Há, então, "preferência pelos exercícios estruturais, de identificação e classificação de unidades/funções morfossintáticas e correção" (MENDONÇA, 2009, p. 207). A concepção de linguagem como instrumento de comunicação predominou nas aulas observadas, pois dentro das práticas didáticas, o estudante torna-se um sujeito obrigado unicamente a capturar a mensagem, a qual se encontrava no LD, um saber externo e indiferente a ele (SILVA; MENDES, 2014, p. 113).

Ao observar as aulas, de modo geral, nota-se o foco no livro didático, o ensino da gramática centrado no modelo tradicional, segundo Travaglia (1996), e os textos usados como pretexto para trabalhá-la. Sendo a gramática normativa aquela que prescreve as regras do bem falar e do bem escrever, tem relação com a concepção de linguagem como expressão do pensamento, que a valoriza, pois segundo Silva e Mendes (2014, p. 111), "a gramática e [o] uso da língua são entendidos como um produto mental, construído unicamente a partir do pensamento". Ao mesmo tempo, tem-se a concepção de linguagem como instrumento de comunicação, que trabalha com a gramática discursiva e a gramática normativa, pois nela a língua "é vista como um código" (TRAVAGLIA, 1996, p. 22).

Ao considerar Antunes (2003, p. 31-32), na maior parte dessas aulas, constata-se que há um ensino da gramática "descontextualizada", "fragmentada", "voltada para a nomenclatura e classificação". Alguns pontos, elencados pelos PCN (BRASIL, 1998, p. 18) sobre o ensino de gramática tradicional nas escolas, podem ser verificados nas aulas observadas, por exemplo, "a desconsideração da realidade e dos interesses dos alunos"; "o ensino associado a exercícios me- 
cânicos de identificação de fragmentos linguísticos em frases soltas"; "a apresentação de uma teoria gramatical inconsistente - uma espécie de gramática tradicional mitigada e facilitada".

Ao retomar os quadros 1 e 2, constata-se que as aulas observadas se centram no ensino da gramática (MENDONÇA, 2009), com foco nas atividades metalinguísticas, pois:

- Há a concepção de língua como sistema, estrutura inflexível e invariável.

- Não houve articulação entre as aulas de gramática e as de leitura e de produção textual.

- Empregou-se a metodologia transmissiva, baseada na exposição dedutiva.

- Os conteúdos gramaticais foram tratados como objetos de ensino, abordados isoladamente, por meio de palavra, frase e período.

- Foco na norma padrão da língua.

- A análise do texto é mais de cunho estrutural e, quando normativa, desconsidera o funcionamento dos gêneros nos contextos de interação verbal.

- Preferência pelos exercícios estruturais, de identificação e classificação de unidades/funções morfossintáticas e correção.

- Foco na atividade metalinguística, ou seja, fala-se sobre a própria língua, descrevendo-a, tomando-a como objeto.

\section{CoNSIDERAÇões FINAIS}

A observação e a análise das aulas permitiram o levantamento de algumas características a respeito do modo como a gramática continua sendo concebida na escola. A lingua mostrou-se una, focada na norma padrão, tendo em vista o trabalho sistêmico com exercícios do livro didático que postulavam um trabalho prescritivo de gramática. Sendo assim, as concepções de linguagem como expressão do pensamento e como instrumento de comunicação nortearam as práticas, pois a língua foi vista como um sistema estável, sem o foco na heterogeneidade linguística. A concepção de linguagem como interação não foi contemplada, pois os conhecimentos linguísticos não foram construídos por meio do diálogo entre professora, aluno e material didático, mas, sim, transmitidos, sendo considerados conhecimentos prontos e acabados.

Tendo em vista as concepções de linguagem, tem-se como concepção de gramática a denominada "normativa". As propostas teóricas, que subsidiam a prática da gramática, em uma nova concepção, a análise linguística, não foram trabalhadas em sala, pois os exercícios focaram em estruturas isoladas da língua. Segundo Silva (2011), poderia ter ocorrido um estudo da lingua em relação à própria língua, para que fosse acompanhada as suas próprias evoluções, coisa que não acontece na gramática normativa.

Dessa forma, apesar de estudos recentes sobre o ensino, centrados na análise linguística, constata-se que, muitas vezes, no contexto escolar, as concepções tradicionais de ensino de gramática imperam. Não se propõe, com este estudo, generalizar os dados e afirmar que em todas as escolas a realidade é a mesma, 
no entanto, esta pesquisa espera contribuir no sentido de possibilitar aos professores (e futuros professores) a reflexão sobre as práticas que realizam em sala de aula e a influência delas na formação do sujeito cidadão.

\section{Grammar teaching in the Elementary School ClassRoom}

Abstract: The present study aims at investigating how grammar teaching approaches have been implemented and accomplished in the elementary school classroom. Thus, classroom grammatical practice is analyzed among $8^{\text {th }}$ grade groups, particularly based on teaching material and teacher's classes. Results reveal that all groups remain characterized by grammar teaching and learning from a traditional standpoint, focusing not only on prescriptive grammar, but also on the text used as a pretext for teaching/studying linguistic aspects. Students' role is limited to receiving knowledge delivered by both teacher and teaching material (text book), which is not in agreement with linguistic analysis proposals widely advocated by scholars of language.

Keywords: Teaching. Grammar. Elementary school.

\section{REFERÊNCIAS}

ANTUNES, I. Aula de Português: encontro e interação. São Paulo: Parábola Editorial, 2003.

ANTUNES, I. Muito além da gramática: por um ensino sem pedras no caminho. São Paulo: Parábola, 2007.

BAGNO, M. Língua, história e sociedade: breve retrospecto da norma-padrão brasileira. In: BAGNO, M. (Org.). Linguística da norma. São Paulo: Loyola, 2002. p. 179-199.

BAKHTIN, M.; VOLOCHINOV, M. Marxismo e filosofia da linguagem. 6. ed. São Paulo: Hucitec, 1992 [1929].

BARBOSA, J. P. Análise e reflexão sobre a lingua e as linguagens: ferramentas para os letramentos. Lingua Portuguesa: Ensino Fundamental, Brasília, v. 19, p. 155-182, 2010.

BRASIL. Secretaria de Educação Fundamental. Parâmetros Curriculares Nacionais: Língua Portuguesa. Brasília: Secretaria de Educação Fundamental, 1998. CEREJA, W. R.; MAGAlHÃES, T. C. Português Linguagens: $8^{\circ}$ ano. 7. ed. São Paulo: Saraiva, 2012.

DORETTO, S. A.; BELOTI, A. Concepções de linguagem e conceitos correlatos: a influência no trato da língua e da linguagem. Revista Encontros de Vista, v. 8. p. 89-103, 2011. Disponivel em: <http://www.encontrosdevista.com.br/ normas_p.php>. Acesso em: 13 nov. 2017.

FRANCHI, C. Criatividade e gramática. Trabalhos em Linguística Aplicada, v. 9, p. 5-45, 1987.

FRANCHI, C. Criatividade e gramática. São Paulo: SE/CENP, 1991. 
GERALDI, J. W. Unidades básicas do ensino de português. In: GERALDI, J. W. (Org.). O texto na sala de aula. São Paulo: Ática, 2002. p. 59-79.

GERALDI, J. W. A análise linguística. In: GERALDI, J. W. (Org.). Portos de passagem. São Paulo: Martins Fontes, 2003. p. 189-222.

KOCH, I. G. V. Desvendando os segredos do texto. São Paulo: Cortez, 2002.

MENDONÇA, M. Análise linguística no ensino médio: um novo olhar, um outro objeto. In: BUNZEN, C.; MENDONÇA, M. (Org.). Português no ensino médio e formação do professor. São Paulo: Parábola Editorial, 2009.

POSSENTI, S. Por que (não) ensinar gramática na escola. Campinas: Mercado de Letras, 1996.

POSSENTI, S. Questões de linguagem: passeio linguístico dirigido. São Paulo: Parábola Editorial, 2011.

REMENCHE, M. L. R.; ROHLING, N. Concepções de análise linguística na formação inicial de professor de Língua Portuguesa. Fórum Linguistic, Florianópolis, v. 12, n. 3, p. 827-843, 2015.

REMENCHE, M. L. R.; ROHLING, N. Prática de análise linguística e formação docente: avanço e desafios. In: OHUSCHI, M. C. G.; MENEGASSI, R. J. Dialogismo, interação em práticas de linguagem no ensino de línguas. Castanhal: UFPA/Faculdade de Letras, 2016. p. 98-122.

SILVA, L. F. G. da; MENDES, M. D. N. Concepções de língua e análise de gramáticas de língua materna: aproximações e distanciamentos. Versalete, Curitiba, v. 2, n. 3, p. 110-121, 2014.

SILVA, W. R. Estudo da gramática no texto. Maringá: Eduem, 2011.

TRAVAGLIA, L. C. Gramática e interação: uma proposta para o ensino de gramática. 8. ed. São Paulo: Cortez, 1996.

TRAVAGLIA, L. C. A gramática na escola: o ensino de gramática. Salto para o Futuro-Boletim, v. 3, p. 73-97, 2007.

Recebido em julho de 2017. Aprovado em setembro de 2017. 